\section{Research Square}

\title{
Evaluation of Anticancer Activity of Neolamarckia Cadamba Leaves and Its Metabolite Profile
}

\section{Shakirah Razali}

International Islamic University Malaysia

\section{Al'aina Firus Khan}

International Islamic University Malaysia

Alfi Khatib

International Islamic University Malaysia

\section{Qamar Uddin Ahmed}

International Islamic University Malaysia

\section{Habibah Hassan}

International Islamic University Malaysia

\section{Suganya Murugesu}

University Putra Malaysia

\section{Tara Jalal}

International Islamic University Malaysia

\section{Muhammad Ichwan}

Faculty of Medicine, Universitas, Sumatera Utara

Jinap Selamat

University Putra Malaysia

\section{Shaden Khalifa}

Stockholm University

Mohamed Abdel-Daim

Suez Canal University

Hesham El-Seedi ( $\nabla$ hesham.el-seedi@biofarm.uu.se )

Uppsala University

\section{Ridhwan Abdul Wahab}

International Islamic University Malaysia

\section{Research Article}

Keywords: Neolamarckia cadamba, breast cancer, gas chromatography, gene expression assay

Posted Date: January 13th, 2021 
DOl: https://doi.org/10.21203/rs.3.rs-124565/v1

License: (c) (1) This work is licensed under a Creative Commons Attribution 4.0 International License. Read Full License 
Evaluation of Anticancer Activity of Neolamarckia cadamba Leaves and its Metabolite Profile

Shakirah Razali ${ }^{1}$, Al'aina Yuhainis Firus Khan ${ }^{1}$, Alfi Khatib, ${ }^{2,3, *}$, Qamar Uddin Ahmed ${ }^{2}$, Habibah Hassan ${ }^{1}$, Suganya Murugesu ${ }^{4}$, Tara K Jalal ${ }^{1}$, Muhammad Ichwan ${ }^{5}$, Jinap Selamat $^{4}$, Shaden A.M. Khalifa ${ }^{6}$, Mohamed M. Abdel-Daim ${ }^{7,8}$, Hesham R. El-Seedi ${ }^{9,10}$ **, and Ridhwan Abdul Wahab ${ }^{1, * * *}$

${ }^{1}$ Department of Biomedical Science, Kulliyyah of Allied Health Sciences, International Islamic University Malaysia, 25200 Kuantan, Pahang DM, Malaysia; shakirahrazali@gmail.com; alainayuhainis@gmail.com; habibahbintuhassan@gmail.com; tarajalal@ymail.com; ridhwan@iium.edu.my.

${ }^{2}$ Pharmacognosy research Group, Department of Pharmaceutical Chemistry, Kulliyyah of Pharmacy, International Islamic University Malaysia, 25200 Kuantan, Pahang DM, Malaysia; alfikhatib@iium.edu.my; quahmed@iium.edu.my.

${ }^{3}$ Faculty of Pharmacy, Airlangga University, Surabaya 60155, Indonesia; alfikhatib@iium.edu.my.

${ }^{4}$ Institute of Tropical Agriculture and Food Security (ITAFoS), University Putra Malaysia, 43400, Serdang, Selangor DE, Malaysia; jinap@upm.edu.my; suganya.murugesu@ gmail.com.

${ }^{5}$ Department of Pharmacology \& Therapeutics, Faculty of Medicine, Universitas, Sumatera Utara, Medan 20222, Indonesia; m.ichwan@usu.ac.id.

${ }^{6}$ Department of Molecular Biosciences, Stockholm University, the Wenner-Gren Institute, SE-106 91 Stockholm; shaden.khalifa@su.se

${ }^{7}$ Department of Zoology, College of Science, King Saud University, P.O. Box 2455, Riyadh 11451, Saudi Arabia 
${ }^{8}$ Pharmacology Department, Faculty of Veterinary Medicine, Suez Canal University, Ismailia 41522, Egypt; abdeldaim.m@vet.suez.edu.eg

${ }^{9}$ Division of Pharmacognosy, Department of Pharmaceutical Biosciences, Uppsala University, Biomedical Centre, 75123 Uppsala, Sweden; hesham.el-seedi@biofarm.uu.se

${ }^{10}$ International Research Center for Food Nutrition and Safety, Jiangsu University, Zhenjiang 212013, China

*Correspondence: ridhwan@iium.edu.my; Tel.: +609-5705262 (R.A.W.); alfikhatib@iium.edu.my; Tel: +609-5704940 (A.K.); hesham.el-seedi@farmbio.uu.se; Tel: +46-700 434343 (H.R.E.-S.)

\begin{abstract}
Neolamarckia cadamba (NC) leaf is traditionally used for the treatment of breast cancer, however, this claim is unverified. This study aimed to evaluate the anti-cancer activities of NC leaf ethanol extract on breast cancer cell line (MCF-7 cells) using in vitro cell viability, cytotoxicity, and gene expression assays followed by gas chromatography analysis. Results revealed inhibition concentration $\left(\mathrm{IC}_{50}\right)$ against $\mathrm{MCF}-7$ at $0.2 \mathrm{mg} / \mathrm{mL}$. The extract exerted a dose and time-dependent inhibitory effect against MCF-7 cells. The cell cycle assay showed that the extract arrested MCF-7 cells in the G0/G1 phase, and apoptosis was observed after 72 hours by Annexin-V assay. The gene expression assay revealed that the cell cycle arrest was associated with the down-regulation of $C D K 2$ and subsequent up-regulation of $p 21$ and cyclin E. The extract induced apoptosis via the mediation of the mitochondrial cell death pathways. Chromatography analysis revealed the contribution of d-pinitol and myo-inositol to the activity observed as the two major bioactive compounds. Overall, the study demonstrated that NC exerts
\end{abstract}


anti-cancer effects on MCF-7 human breast cancer cells through induction of apoptosis and cell cycle arrest thus justifying its traditional use for breast cancer treatment in Malaysia.

Keyword: Neolamarckia cadamba, breast cancer, gas chromatography, gene expression assay

\section{Introduction}

Breast cancer is the most commonly occurring cancer in women and the second most common cancer overall in terms of fatality after lung cancer ${ }^{1}$. The rate of cases of breast cancer patients is increasing every year, both in developed and developing countries ${ }^{2}$. It is estimated that 26 million new cancer cases and 17 million cancer deaths are likely to occur per year globally by $2030{ }^{3}$. In Asia alone, the incident in 2008 to 2030 is estimated to rise from 6.1 million to 10.7 million cancer cases and 4.1 million to 7.5 million deaths ${ }^{4}$. Malaysia is one of the Asian countries with an increased prevalence of breast cancer cases ${ }^{5}$ affecting both genders but increased exponentially with age in women and thus accounted for the leading cause of cancerrelated death among women in Malaysia ${ }^{6}$. Surgery, radiotherapy, chemotherapy, hormonal therapy, and gene-targeted therapy have been used in treating breast cancer patients. The advances of current treatments and detecting methods have attributed to the increase of the survival rate ${ }^{7}$. Unfortunately, the treatment causes short-term and long-term side effects for the patients. Moreover, studies have demonstrated that the burden of the cost related to cancer

treatment is rising ${ }^{7,8}$. Therefore, the use of natural sources as an alternative, effective, and noninvasive entities to treat cancer is warranted.

According to the World Health Organization (WHO), there are many countries including developing countries where people are still using plants and natural source products for therapeutic purposes ${ }^{9}$. About $60 \%$ of anticancer agents in the world have been originated from 
natural sources ${ }^{10}$. The natural-derived compounds are readily available, generally more tolerated, and considered non-toxic to normal human cells ${ }^{11}$.

Neolamarckia cadamba (family: Rubiaceae) is a tree that is used for treating various illnesses. This underexplored evergreen tropical plant has been widely used in the Ayurvedic medicine system of India in treating eye infection, skin diseases, dyspepsia, gum related troubles, stomatitis, cough, fever, anemia, blood disorders, and stomach pain ${ }^{12,13}$. The leaves of this plant have been shown to possess several pharmacological properties including antioxidant ${ }^{14,15}$, antidiabetic ${ }^{16}$, antitumor ${ }^{17}$, anti-inflammatory, antipyretic, analgesic ${ }^{18}$, antimicrobial ${ }^{19}$, and anticancer effect ${ }^{20}$. Furthermore, the $N$. cadamba leaves have also been used as a topical application for the treatment of breast cancer. However, this traditional application has never been scientifically investigated to verify the claims. Therefore, the purpose of the study was to evaluate the anticancer effects of $N$. cadamba leaves extract on breast cancer cell line (MCF-7) with emphasis on the mechanism of action, i.e., apoptosis induction and cell cycle arrest. As well, characterization of $N$. cadamba leaves extract was carried out using gas chromatographymass spectrometry (GCMS) approach to identify bioactive compounds.

\section{Results}

Gas Chromatography-Mass Spectrometry (GCMS) analysis of NC. Fig. S1 and Table 1 present the putative compounds present in the NC leaves $80 \%$ ethanol extract. The chromatogram showed the highest peak area corresponding to d-pinitol, followed by myoinositol, oleic acid, hexadecanoic acid, and octadecanoic acid. Table 1 presents tentative identified compounds' retention time, $\%$ area peak, molecular formula, and similarity index. 
Table 1. The putative compounds in NC leaves extract identified by GCMS.

\begin{tabular}{ccccc} 
No. & $\begin{array}{r}\text { Retention } \\
\text { time }\end{array}$ & Name of compound & Area & Similarity \\
& & \% & index \\
\hline $\mathbf{1}$ & 14.25 & Phenol, 2,4-bis(1,1- & 0.21 & 93 \\
& & dimethylethyl)- & & \\
$\mathbf{2}$ & 16.08 & Levoglucosan & 0.23 & 91 \\
$\mathbf{3}$ & 20.36 & $\beta$-D-(+)-Talopyranose & 0.38 & 92 \\
$\mathbf{4}$ & 20.78 & D-pinitol & 14.18 & 86 \\
$\mathbf{5}$ & 20.98 & Hexadecanoic acid & 0.52 & 91 \\
$\mathbf{6}$ & 22.13 & Myo-inositol & 7.98 & 90 \\
$\mathbf{7}$ & 23.22 & Oleic acid & 0.66 & 89 \\
$\mathbf{8}$ & 23.48 & Octadecanoic acid & 0.43 & 90 \\
\hline
\end{tabular}

Breast cancer cells (MCF-7) viability after NC treatment. The anticancer activity of NC leaves $80 \%$ ethanol extract was investigated against MCF-7 cells. The cell viability was directly tested using the trypan blue exclusion assay method where the dead cells were stained blue. Fig. 1 (A) shows the anti-proliferative activity of NC leaves $80 \%$ ethanol extract on MCF-7 cells after 72 hours of incubation. The finding revealed an $\mathrm{IC}_{50}$ of $206.0 \pm 3.4 \mu \mathrm{g} / \mathrm{mL}$. The cell viability was found to decrease with the increasing concentration of the extract used. Fig. 1 (B) demonstrates the $\mathrm{IC}_{50}$ value of $\mathrm{NC}$ to inhibit MCF-7 growth with cell viability percentage difference between $\mathrm{NC}$ and UT by $6.3 \%, 12.2 \%, 23.1 \%, 35.4 \%$ at $24 \mathrm{~h}, 48 \mathrm{~h}, 72 \mathrm{~h}$, and $96 \mathrm{~h}$, respectively. From the 
findings, it can be seen that NC inhibition effect on MCF-7 growth increased over time. Fig. 1 (C) depicts the image of MCF-7 treated with NC in comparison to the untreated as a control. The image shows the cells exhibiting a distinguished plasma membrane with intact nuclei and were seen to grow adjacent to the neighbouring cells in monolayer. Most of the cells were attached to the tissue culture plate. In contrast, cells treated with NC extract for $72 \mathrm{~h}$ showed apoptotic-like features including cell rounding, loss of contact with the adjacent cells, cell shrinkage, and formation of apoptotic bodies. Fig. 1 (D) presents the viability of normal HDF cells exposed to NC leaves $80 \%$ ethanol extract for $72 \mathrm{~h}$. The graph reveals that NC ethanol extract has slight toxicity on HDF cells by inhibiting cell growth by $19.5 \%$ when compared to UT. Overall the NC ethanol extract exhibited a dose and time inhibition pattern related to the MCF-7 cells growth and slight toxicity on normal $\mathrm{HDF}$ cells. The $\mathrm{IC}_{50}$ obtained was used for further investigation in this study. 
A)

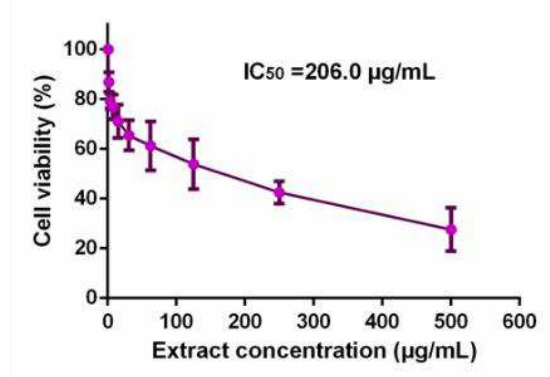

c)

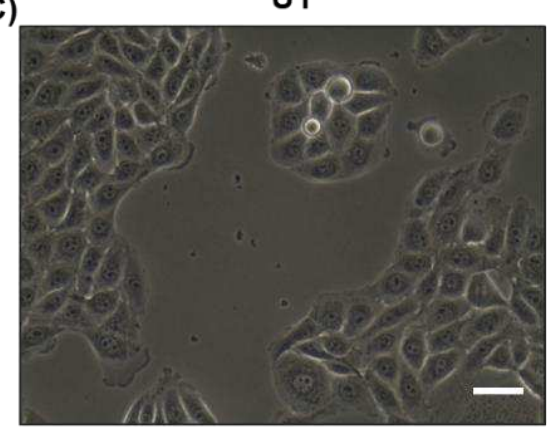

D)
B)

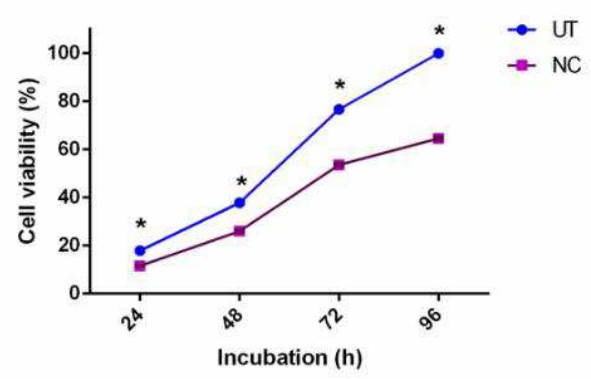

NC

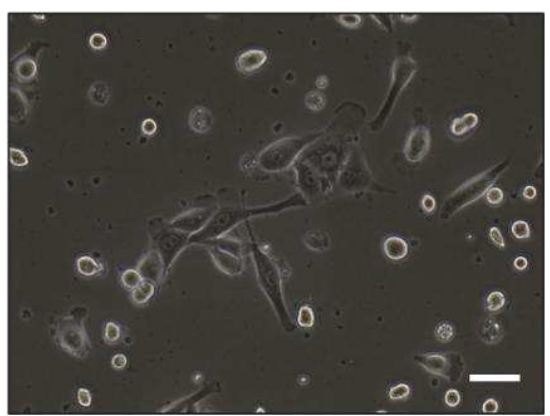

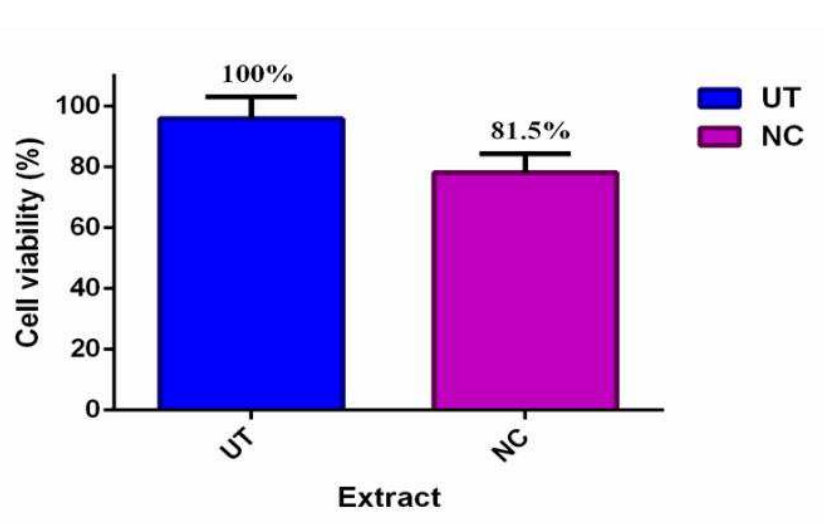

Figure 1. The effect of NC leaves $80 \%$ ethanol extract on MCF-7 cells viability. (A) The median concentration of MCF-7 treated with $\mathrm{NC}$ leaves $80 \%$ ethanol extract for $72 \mathrm{~h}$. (B) Antiproliferative effect of NC leaves $80 \%$ ethanol extract at $24,28,72$, and $96 \mathrm{~h}$ with untreated cells (UT) as controls. (C) Image of MCF-7 cells NC leaves $80 \%$ ethanol extract treated and untreated at 72 h. (D) Cytotoxic effect of NC leaves $80 \%$ ethanol extract median concentration on normal human dermal fibroblast (HDF) cells at $72 \mathrm{~h}$ incubation. The results presented as mean $\pm \mathrm{SD}(\mathrm{n}=$ 3). Bar graph $=25 \mu \mathrm{m}$. * indicates $\mathrm{p}<0.05$. 
Cell cycle analysis of NC against MCF-7 cells. To understand the growth inhibition finding earlier, NC leaves $80 \%$ ethanol extract treated MCF-7 cells were subjected to cell cycle analysis with UT served as control. Fig. 2 (A) demonstrates MCF-7 treated with NC leaves $80 \%$ ethanol extract and UT DNA histogram at $72 \mathrm{~h}$ of incubation which indicates NC leaves $80 \%$ ethanol extract exerted MCF-7 arrest in G1/G0 compared to UT. Fig. 2 (B) shows the proportion of cells according to cell cycle phase from Fig. 2 (A). The graph reveals NC leaves $80 \%$ ethanol extract significantly induced G1/G0 arrest in MCF-7 cells evidenced by the increase of cell population by $22.9 \%$ in G1/G0 and simultaneous decrease of G2/M by $21.9 \%$ compared to UT.

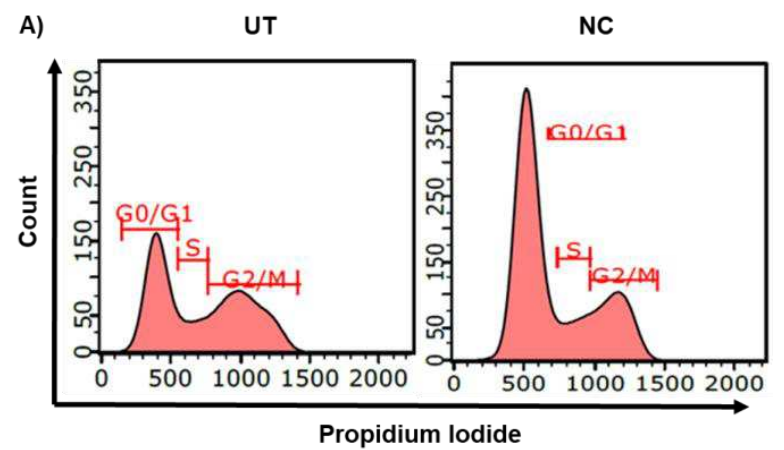

B)

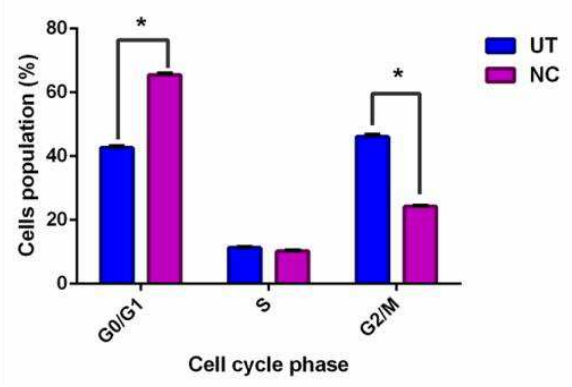

Figure 2. The effect of NC leaves $80 \%$ ethanol extract on the MCF-7 cell cycle. (A) Representation of DNA histogram of NC leaves $80 \%$ ethanol extract-treated cells, with UT as control at $72 \mathrm{~h}$ of incubation. DNA histograms display cell cycle phases of treated cells, namely G1/G0, S, and G2/M ( $=3$ ). (B) The proportion of cells according to cell cycle 
phase are presented in percentage mean $\pm \mathrm{SD}(\mathrm{n}=3) *$ indicates $\mathrm{p}<0.05$ concerning untreated.

Apoptosis analysis of NC leaves $80 \%$ ethanol extract against MCF-7 cells. As evidenced earlier, NC leaves $80 \%$ ethanol extract showed growth inhibition and cell death, hence further investigation was conducted to evaluate the possibility of cells to undergo apoptosis using flow cytometer analysis. Annexin-V assay helped to differentiate individual cells in live, early apoptotic, late apoptotic, and necrotic quadrants following $72 \mathrm{~h}$ of $\mathrm{NC}$ leaves $80 \%$ ethanol extract treatment to MCF-7 cells. Fig. 3 (A) shows MCF-7 cells NC leaves $80 \%$ ethanol extract treated and UT dot plot distribution in quadrants. The Annexin-V assay revealed NC leaves $80 \%$ ethanol extract-treated cells induces early and late apoptosis by $12.0 \%$ and $32.1 \%$ compared to UT. On the contrary, UT cells are majorly located in the live quadrant. Fig. 3 (B) demonstrates the proportion percentages of apoptotic (early and late apoptosis) and live cells of NC leaves $80 \%$ ethanol extract treated and UT MCF-7 cells. The proportion of apoptotic percentage from NC leaves $80 \%$ of ethanol extract-treated cells was significantly higher by $44.3 \%$ compared to UT $8.6 \%$. While the proportion of live cells percentage was higher in UT MCF-7 by $91.5 \%$ compared to NC treated cells by $65.7 \%$. 


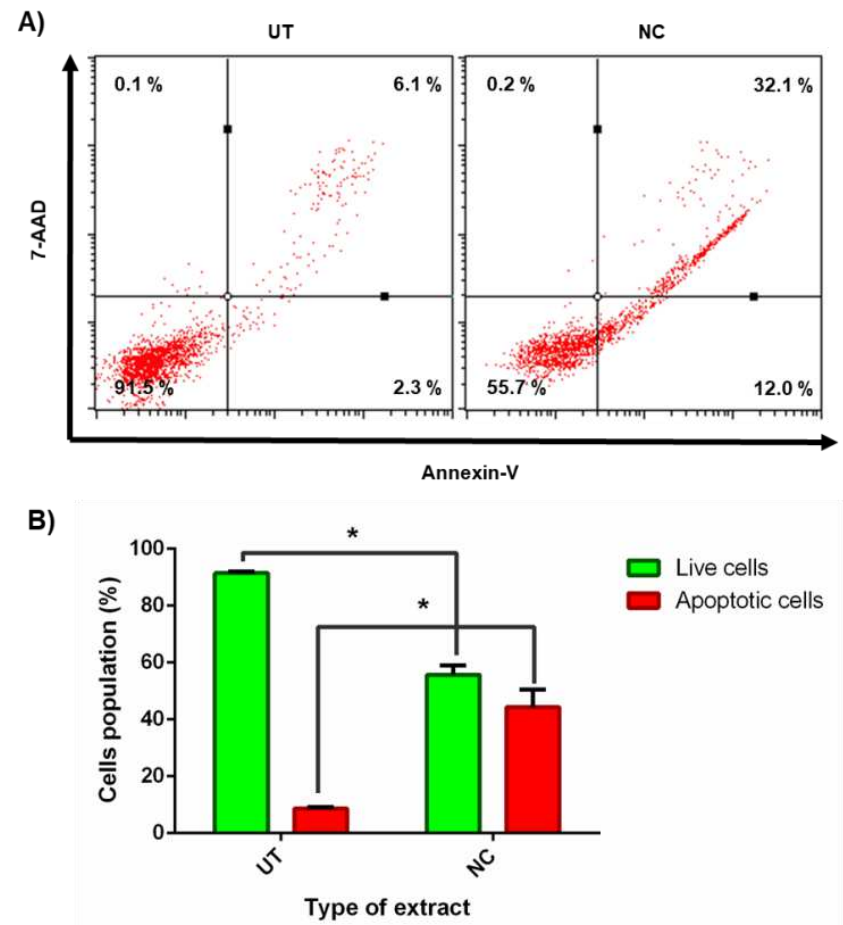

Figure 3. The effect of NC leaves $80 \%$ ethanol extract on MCF-7 cells. (A) Representation of dot plot distribution of cells in living, death, early and late apoptosis quadrants of MCF-7 cells treated with NC leaves $80 \%$ ethanol extract at $72 \mathrm{~h}$ with UT as control, $(\mathrm{n}=3)$. (B) The proportion percentages of apoptotic (early and late apoptosis) and live cells are presented as percentage mean $\pm \mathrm{SD}(\mathrm{n}=3) . *$ indicates $\mathrm{p}<0.05$ concerning untreated.

Effects of NC leaves $80 \%$ ethanol extract on gene expression of MCF-7. A deeper investigation was further performed to investigate gene expression of $\mathrm{NC}$ leaves $80 \%$ ethanol extract supplement to MCF-7 cells with regards to cell cycle arrest and apoptosis induction. Five genes related to apoptosis were measured for their expressions through qPCR assay viz. Bax, Bcl-2, caspase-9, caspase-7, and cytochrome c. The expression of cell cycle-related genes on MCF-7 treated cells with a growth arrest at the G0/G1 phase, cyclin E, CDK2, and p21 were studied. Fig. 4 shows that upon NC leaves $80 \%$ ethanol extract treatment, the expression of cyclin $E$ and $p 21$ were found to be up-regulated with $1.6 \pm 0.54$ and $1.7 \pm 0.02$ folds, 
respectively. Meanwhile, CDK2 was down-regulated with $0.9 \pm 0.07$ folds. From this result, the up-regulated expression of $p 21$ in $\mathrm{NC}$ treated cells indicates that the $p 21$ inhibits the activity of $C D K 2$ and cyclin $E$ catalytic complex formation which blocks the progression to the next stage of the cell cycle.

In Fig. 5 (a), Bax (pro-apoptotic) and cytochrome $c$ were down-regulated by NC leaves $80 \%$ ethanol extract for $2.1 \pm 0.07$-fold decreases and $5.1 \pm 0.42$-fold decreases, respectively whereas $B c l-2$ was down-regulated for $0.9 \pm 0.04$-fold decreases. Meanwhile, in Figure 5(B) caspases family (caspase-9 and caspase-7) expressions were up-regulated with NC leaves $80 \%$ ethanol extract treatment by $3.1 \pm 0.65$ and $1.8 \pm 0.19$-fold increases, respectively. The up-regulation of Bax, cytochrome $c$, and caspases family corresponded with the down-regulation of $B c l-2$ gene suggesting that $\mathrm{NC}$ extract treatment lowered cell survival and induced apoptosis via the intrinsic mitochondrial pathway.

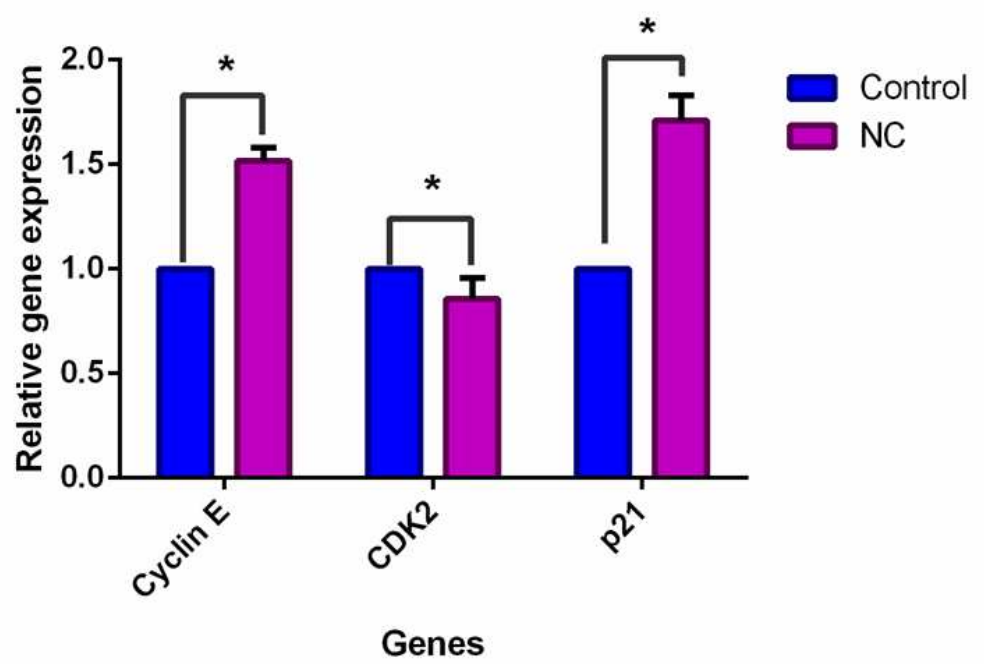

Figure 4: Effect of NC leaves $80 \%$ ethanol extract on cell cycle-related gene expression upon treatment with IC50 for $72 \mathrm{~h}$. Relative expression for cyclin $E, C D K 2$, and $p 21$ were calculated by measuring the fold change with GAPDH and $\beta$-actin as reference genes in 
untreated cells (the ratio was equal to 1 ). Data presented in mean \pm standard deviation of triplicates of the experiment. $*$ indicates a significant difference when $\mathrm{p}<0.05$.

A)

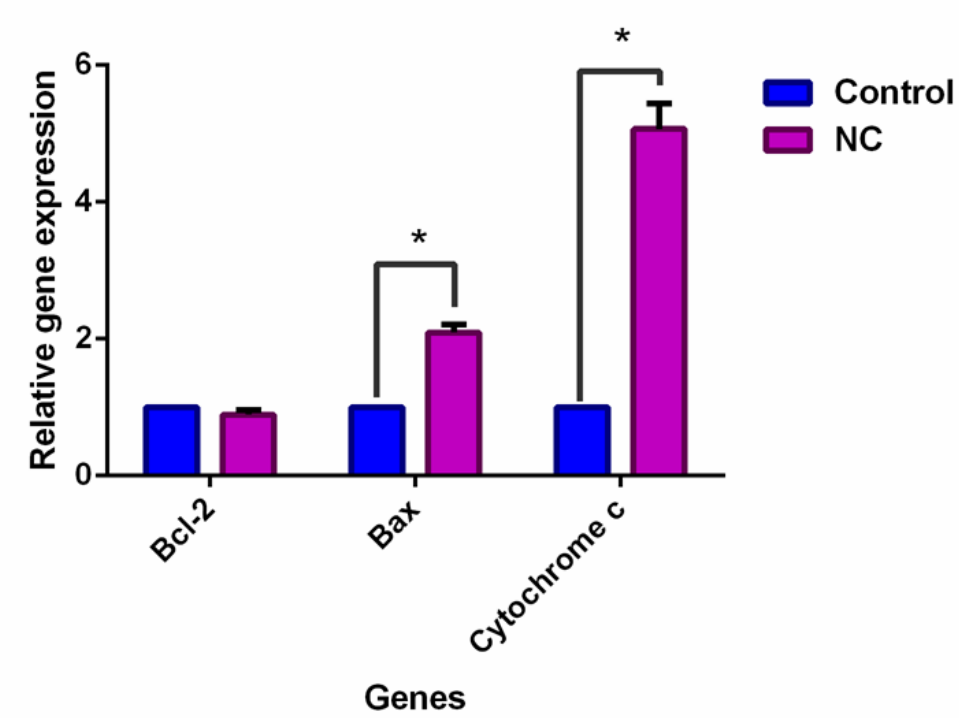

B)

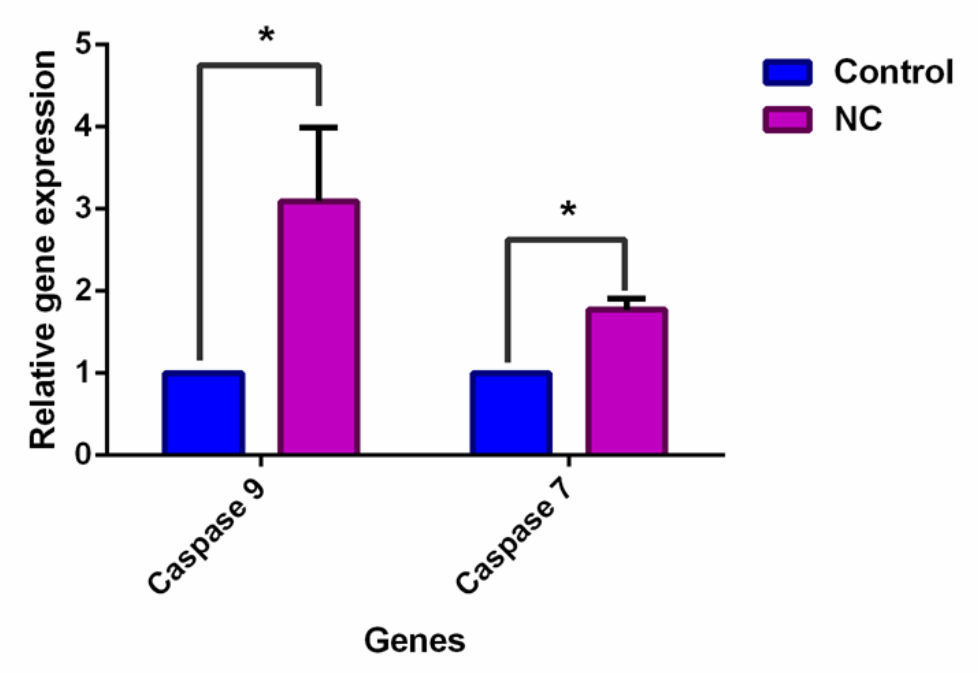

Figure 5. Effect of NC leaves $80 \%$ ethanol extract on apoptosis-related gene expression upon treatment with $\mathrm{IC}_{50}$ for $72 \mathrm{~h}$. Relative expression for (a) Bcl-2, Bax and cytochrome c, and (b) caspase- 9 and caspase- 7 were calculated by measuring the fold change with GAPDH and $\beta$-actin as a reference gene in untreated cells, whose ratio was equal to 1 . Data presented in mean \pm 
standard deviation of triplicates of the experiment. * indicates a significant difference when $p<$ 0.05 .

\section{Discussion}

Throughout the whole world, breast cancer is affecting women the most compared to other types of cancers with a high incidence and mortality rate ${ }^{21,22}$. Additionally, there are some undocumented and unverified claims for $N$. cadamba leaf that it is used to treat breast cancer in different parts of Malaysia, however, no scientific study using breast cancer cell lines has ever been carried out to confirm its potential in the management of breast cancer. Hence, this study was performed to verify $N$. cadamba leaf extract as a potential anticancer agent with minimal toxicities. In this study, NC leaf's $80 \%$ ethanol extract was initially characterized with GCMS and then assessed for its in vitro anticancer properties and mechanism of action using MCF-7 cells. Phytochemical characterization of NC leaf's $80 \%$ ethanol extract through GCMS analysis identified eight putative bioactive compounds including d-pinitol, myo-inositol, oleic acid, hexadecanoic acid, octadecanoic acid, $\beta$-D-(+)-talopyranose, levoglucosan, and phenol, 2, 4-bis (1,1-dimethylethyl).

Among the compounds, D-pinitol was found as the most abundant one. D-pinitol is a natural, sugar-like cyclitol, a cyclic polyol found in a variety of plants including soybean and has been reported to exert diverse biological activities particularly antioxidant, antiviral, antidiabetic, anti-inflammatory, and anticancer. D-pinitol has been reported to inhibit prostate cancer metastasis through inhibition of $\alpha \mathrm{V} \beta 3$ integrin by modulating $F A K, c-S r c$, and $N F-\kappa B$ pathways 23. Furthermore, a study revealed that d-pinitol was able to induce apoptosis in MCF-7 by upregulating Bax and down-regulating $B c l 2$ expressions. It was also demonstrated that D-pinitol promoted apoptosis in MCF-7 cells via induction of p53 and Bax and inhibition of $\mathrm{Bcl}-2$ and $\mathrm{NF}$ - 
$\kappa B^{24}$. Myo-inositol, the next most abundant bioactive compound in $N$. cadamba leaf's extract has been earlier isolated from fresh samples of Cosmos caudatus ${ }^{25}$ and Sapindus mukorossi ${ }^{26}$. Myo-inositol has been currently used clinically to treat polycystic ovary syndrome (PCOS) ${ }^{27}$.

Hexadecanoic acid was identified in our study as another bioactive compound and identified earlier from methanol (44.88\%) and hexane (17.96\%) extracts of $N$. cadamba leaves. Additionally, octadecanoic acid was also found in methanol, ethyl acetate, chloroform, and hexane extract ${ }^{28}$. N-hexadecanoic acid found in Kigelia pinnata leaves had caused cytotoxicity in HCT-116 cell lines ${ }^{29}$. Moreover, octadecanoic acid has induced apoptosis in breast cancer cells ${ }^{30}$. Oleic acid found in almond oil (Prunus dulcis) has displayed antiproliferative and anticancer effects on colon carcinoma cells ${ }^{31}$. Meanwhile, the ability of phenol, 2,4-bis (1,1dimethylethyl) compound docked with Bcl-2 showing low binding affinity $(-7.4 \mathrm{kcal} / \mathrm{mol})$ after caryophyllene compound $(-7.5 \mathrm{kcal} / \mathrm{mol})$ indicated the potential of Solanum trilobatum extract compounds as a potent anticancer agent ${ }^{32}$.

The results showed that the population of MCF-7 cell lines was reduced to 50\% from 100\% of viable cells. NC extract exhibited a growth inhibitory effect towards MCF-7 in a dose and time-dependent manner in which the percentage of viable cells decreased in correspondence with the increase of NC extract concentration. Different bioactive compounds were reported in $N$. cadamba leaf using different solvents and associated with various biological activities including antioxidant, anticancer, or anti-tumour activity ${ }^{28}$. Sun and Liu described that the existence of different components in the natural sources may produce additive and synergistic effects rather than a single effect ${ }^{33}$. The biochemical and different morphological changes such as cell shrinkage, cell blebbing, the formation of apoptotic bodies, nuclear condensation, DNA fragmentation are the hallmark of apoptosis ${ }^{34}$. The apoptotic-like features of MCF-7 cells were 
observed under a phase-contrast inverted microscope. Cell rounding, cell shrinkage, membrane blebs, loose contact with adjacent cells, the formation of apoptotic bodies, and cell vacuolization were seen in the treated MCF-7 cells. The appearance of apoptotic cell features has also been reported in MCF-7 cells treated with rapamycin under inverted microscope observation ${ }^{35}$. Alteration in the morphology of MCF-7 cells following the NC extract treatment indicated that the cells experienced apoptosis ${ }^{36}$. One of the main challenges with current treatments is the capacity to hit cancer cells without killing normal cells surrounding the cancer cells. However, the findings in this study revealed that NC extract was slightly toxic towards normal cells.

Inhibition of proliferation and/or induction of apoptosis in cancer cells is considered one of the main important criteria for many anti-cancer agents ${ }^{37}$. Flow cytometric analysis in the present study revealed that MCF-7 cells underwent apoptosis upon treatment with $\mathrm{NC}$, abundantly in late apoptosis. A similar finding was found on MCF-7 cells after the treatment with rapamycin in which late apoptosis up to $23.2 \%$ had been reported. Early apoptosis was detected in the present study indicating the externalization of negatively charged phosphatidylserine (PS) ${ }^{38,39}$, which mainly is localized in the inner layer of the membrane. Late apoptosis is also known as secondary necrosis, causing loss of membrane integrity ${ }^{40}$.

The cell cycle consists of consecutive four phases that are important in cell division and cell proliferation. The unscheduled proliferation and genomic instability give rise to the accumulation of tumour cells ${ }^{41}$. The finding in this study suggests that $\mathrm{NC}$ extract caused cell cycle arrest at the G0/G1 phase in MCF-7 cells after 72 hours of exposure. The results clearly showed a significant increase of cell distribution in the G0/G1 phase accompanied by a decrease of cell distribution in phase S. Accumulation of cells in the G0/G1 phase has been reported in MCF-7 cancer cells ${ }^{33,42}$ and other cancer cell lines ${ }^{43,44}$ after plant extracts treatment. A similar finding 
was also reported in a study in which epirubicin caused the G0/G1 cell cycle arrest on MCF-7 and T47D cells ${ }^{45}$. Upon the detection of DNA damage, cell cycle checkpoints stop the progression of the cell cycle from one phase to the next phase to ensure the fidelity of genetic information $^{46}$. The arrest of MCF-7 cells at the G0/G1 phase prevents the cells from entering the next phases of the cell cycle, the $S$ and G2/M phase, which eventually inhibits the synthesis of DNA and suppresses proliferation of the cells. To find out the possible mechanism of the extract to induce apoptosis and cell cycle arrest in MCF-7 cells, qPCR assay was performed. The upregulation of cytochrome $c$ links with the up-regulation of Bax expression and down-regulation of Bcl-2. Bax executes its action on mitochondria by promoting the release of cytochrome $c$, via increasing the permeability of mitochondria membrane, into the intracellular space ${ }^{47}$. The inhibition of $B c l-2$ activity involved with the heterodimer formation on $B c l-2$ by $B a x$ gene to counteract the anti-apoptotic effects of $\mathrm{Bcl}-2^{48}$. The liberation of cytochrome c would activate apoptosome which then activates caspase 9 and the effector caspases, caspase 3 and caspase 7 leading to cell death ${ }^{49,50}$. The morphological and biochemical changes are associated with caspases activation upon apoptotic stimuli ${ }^{51}$. The up-regulation of caspase- 9 and caspase-7 expressions were detected upon NC treatment on MCF-7 cells. Activation of the effector caspases via proteolytic cleavage by caspase-9 and cytochrome $c$ are believed to play a crucial role in the execution of apoptosis ${ }^{52}$. These results might suggest that NC extract exerts apoptosis through the intrinsic pathway. The expression of p21 (tumour suppressor gene) stops the cell cycle progression from dividing damaged cells ${ }^{53}$. The binding of $p 21$ on $C D K s$ or cyclin-CDK complexes disrupts these interactions and inhibits cell cycle progression ${ }^{54,55}$. Up-regulated $p 21$ and down-regulated $C D K 2$ support the G0/G1 cell cycle arrest in the previous data. Interestingly, cyclin $E$ in the present study was found to be up-regulated, which suggested that cyclin $E$ 
independently binds to $C D K 2$ for halting the cell cycle. It was suggested that inhibition of breast cancer cell MCF-7 proliferation may be linked to the up-regulation of cyclin $E$ and $p 21$ as well as down-regulation of $C D K 2$ upon $\mathrm{NC}$ extract treatment. In addition, $p 21$ was found to be associated with apoptosis. A study found the cytochrome $c$ blockage and caspase-3 inactivation in HCT116 p21-/- but not in HCT p53-/- and HCT116 Bax-/- of colon cancer cells after treatment with curcumin. The study also found a reduced expression of Apaf-1 in the HCT116 p21-/- cells whereas it was not expressed in wild type ${ }^{56}$. Cytochrome $c$ release and Apaf-1 are required for caspase-9 activation of the intrinsic apoptosis pathway ${ }^{57}$, which in turn activate executioner caspases, including caspase-3 and caspase-7. Based on the present findings, it is suggested that $p 21$ up-regulated expression may be involved in apoptosis activities by promoting the cytochrome $c$ release to inhibit the proliferation of MCF-7 cells upon treatment.

\section{Conclusions}

The present data suggested that NC ethanol extract inhibits cellular growth in MCF-7 cells by inducing apoptosis and cell cycle arrest. As supported by the flow cytometric analysis, up-regulation of Bax, cytochrome c, and caspases (caspase-9 and -7) with down-regulation of Bcl-2 in MCF-7 cells suggesting that NC extract promotes apoptosis via the intrinsic pathway. In addition, up-regulation of $p 21$ and cyclin $E$, and down-regulation of $C D K 2$ expressions suggesting that cell cycle arrest occurs in MCF-7 cells upon NC treatment. Through this finding, the up-regulation of cytochrome $c$ may be associated with the up-regulation of p21 which ultimately leads to apoptosis induction. Other than that, up-regulation of cyclin $E$ alone may have caused cell cycle arrest, in which overexpression may reduce the proliferation of MCF-7 cells. The GCMS analysis revealed that d-pinitol, myo-inositol, hexadecanoic acid, octadecanoic acid, oleic acid, and phenol, 2,4-bis (1,1-dimethylethyl) compounds may contribute to the 
aforementioned anticancer effects of the NC extract. Nevertheless, other compounds that could not be identified in the GCMS library might also play roles in the anticancer effects of the NC ethanol extract. Therefore, further research is required to identify other possible bioactive compounds and evaluate all the possible bioactive anticancer candidates. Additionally, studies involving in vivo models are necessary to further analyze NC anticancer effects and mechanism of action.

\section{Materials and Methods}

Materials and chemicals. The GCMS reagents were purchased from Sigma Aldrich, USA (Pyridine and N-Methyl-N-(trimethylsilyl)tri-fluoroacetamide-MSTFA) and Supelco, USA (methoxyamine $\mathrm{HCl}$ ). The normal human fibroblast (HDF) and human breast adenocarcinoma (MCF-7) were obtained from American Type Culture Collection (ATCC), USA. All cells were maintained in complete growth medium (CGM) consists of Dulbecco's modified Eagle medium (DMEM) (Nacalei Tesque, Japan), 10\% Fetal Bovine Serum (Nacalei Tesque, Japan), and 1\% of Penicillin-Streptomycin (Nacalei Tesque, Japan). The phosphate buffer saline (PBS) from Gibco, USA was used for cell washing purposes. Reagents for apoptosis (Nexin reagent) and cell cycle reagent were purchased from Merck Millipore, USA. Kits used for mRNA analysis were purchased from Analytik Jena, Germany (InnuPREP DNA/RNA mini kit), BIOLINE, UK (SensiFAST cDNA synthesis and SensiFAST SYBR ${ }^{\circledR}$ No-ROX kits), and Integrated DNA technologies, Singapore (primer).

Preparation of Neolamarckia cadamba leaves $80 \%$ ethanol extract (NC). Fresh leaves of $N$. cadamba were collected from Balok, 25200 Kuantan, Pahang DM, Malaysia, and deposited (voucher specimen \#: PIIUM 0266) in the Herbarium, Kulliyyah of Pharmacy, IIUM, Malaysia. The leaves were washed and air-dried. The dried leaves were pulverized and soaked in $80 \%$ 
ethanol three times on a sonicator machine. The extract was filtered, concentrated by a rotatory evaporator, and freeze-dried. It was stored at $-20{ }^{\circ} \mathrm{C}$ until further usage. The extract was dissolved in $80 \%$ ethanol to obtain a stock solution of $100 \mathrm{mg} / \mathrm{mL}$. Working solutions were prepared fresh from ethanol stock in DMEM medium by serial dilutions. The solutions were then filtered with a sterilized $0.22 \mu \mathrm{L}$ syringe filter before use in an in vitro assay ${ }^{25}$.

Gas Chromatography-Mass Spectrometry (GCMS) Analysis of NC. Derivatization of the samples was performed for GCMS analysis following the method described ${ }^{25}$. Briefly, about 50 $\mu \mathrm{L}$ pyridine, $100 \mu \mathrm{L}$ of methoxyamine $\mathrm{HCl}(20 \mathrm{mg} / \mathrm{mL}$ in pyridine), and $300 \mu \mathrm{L}$ of MSTFA were added to the extract. The extract solutions were filtered and covered with aluminium foil to be left overnight at room temparature before analysis. The GCMS analysis was carried out using GCMS-TQ8040 (Shimadzu, Japan) where the analysis was carried out using a DB-5MS 5\% phenyl methyl siloxane $(30 \mathrm{~mm} \times 0.25 \mathrm{~mm}$, i.d. $\times 0.25 \mu \mathrm{m}$ thickness $)$. The initial oven temperature used was set to $50{ }^{\circ} \mathrm{C}$ for 5 mins and raised to $200{ }^{\circ} \mathrm{C}$ at the rate of $5{ }^{\circ} \mathrm{C} /$ minute and held for 5 mins before reaching the target temperature of $300{ }^{\circ} \mathrm{C}$ at the same rate. The carrier gas applied was helium with a flow rate of $1.0 \mathrm{~mL} / \mathrm{min}$ while the injector and detector temperature were set up to $250{ }^{\circ} \mathrm{C}$ and $280{ }^{\circ} \mathrm{C}$, respectively.

Effect of NC on cell viability of MCF-7 and HDF cells growth. All cells were maintained in a sterilized environment set to $37{ }^{\circ} \mathrm{C}$ with $5 \% \mathrm{CO}_{2}$ humidified atmosphere. The cells viability of $\mathrm{NC}$ treated cells was measured using the trypan blue exclusion (TBE) method as previously described $^{58}$. In determining the median concentration of NC on MCF-7 cells, the cells were seeded at $4.7 \times 104$ cells $/ \mathrm{mL}$ in 6-well plates. After overnight, different concentrations of NC prepared by serial dilution $(500.0,250.0,125.0,62.5,31.3,15.6,7.8,3.9,1.95,0.9 \mu \mathrm{g} / \mathrm{mL})$ were added to MCF-7 cells for $72 \mathrm{~h}$ before cells density evaluation using TBE. MCF-7 cells were 
exposed to the $\mathrm{NC}$ for $24,48,72$, and $96 \mathrm{~h}$ prior evaluation with $\mathrm{TBE}$ assay to determine the MCF-7 growth exposure with NC. The cytotoxicity of NC against normal HDF cells was determined by examining the $\mathrm{IC}_{50}$ value of $\mathrm{NC}$ after $72 \mathrm{~h}$. The untreated cells were not exposed to $\mathrm{NC}$ and were used as a negative control.

Cell Cycle Analysis. MCF-7 cells collected from the well were prepared in triplicate prior to staining with cell cycle reagent following the manufacturer's instructions. The PI stained cells were observed using a flow cytometer Guava EasyCyte system ${ }^{58}$.

Apoptosis Analysis Using Annexin V. Briefly, MCF-7 cells were exposed to NC for $72 \mathrm{~h}$. The collected cells were treated with the FITC Annexin-V Apoptosis Detection Kit I, following the manufacturer's instructions. The cells were treated with $1 \mathrm{X}$ Binding buffer, FITC Annexin-V, and propidium iodide (PI) before their application to the flow cytometer Guava EasyCyte system (EMD Millipore, Germany) ${ }^{58}$.

Real Time Quantitative PCR (RT-qPCR) analysis of target genes. The quantification of the mRNA expression of the targeted primer mRNA corresponding to apoptosis, cell cycle, and metastasis was carried out following our previously published work ${ }^{59}$. Briefly, the RNA extraction kit was used to extract the total RNA from the plant treated and non-treated MCF-7 cells after $72 \mathrm{~h}$. The RNA's purity and integrity were evaluated prior to complementary DNA (cDNA) synthesis. The cDNA was prepared using a cDNA synthesis kit with 200 ng of RNA template following the manufacturer's instructions. Primers were selected from the National Centre for Biotechnology Information (NCBI) database based on the criteria listed below,

i. $\quad$ Melting temperature, $\operatorname{Tm}\left(59-65^{\circ} \mathrm{C}\right)$

ii. Amplicon size (70-150 bases) 
iii. Forward and reverse primers (spanning exon-exon junctions)

iv. Primer's $3^{\prime}$ end with a $\mathrm{C}$ or $\mathrm{G}$ residue

v. GC content (40-60\%)

vi. Primers sequence (18 to 25 nucleotides)

The PCR amplifications were conducted using SYBR green in CFX96 Touch ${ }^{\mathrm{TM}}$ Real-Time PCR (Bio-Rad, USA). The efficiency of the primer PCR was evaluated using 1:10 serial dilutions of the cDNA sample. The standard curve's amplification efficiency (E) range was set between 93.5\% to $115.4 \%$, while the correlation coefficients (R2) ranged from 0.984 to 0.998 . The optimized parameters of the amplifications include $2 \mathrm{~min}$ at $50{ }^{\circ} \mathrm{C}, 10 \mathrm{~min}$ at $95{ }^{\circ} \mathrm{C}$, and 45 cycles of $15 \mathrm{~s}$ at $95^{\circ} \mathrm{C}$ and $1 \mathrm{~min}$ at $60{ }^{\circ} \mathrm{C}$. The CFX Manager Software was used to analyze the results obtained by applying the threshold cycle (CT) values. The reference genes used were glyceraldehyde 3-phosphate dehydrogenase (GAPDH) and $\beta$-actin (ACTB). The nucleotide sequences and genes observed are tabulated (Table 1) in the results section while the primers' detailed information is displayed in the supplementary file (Table S1).

Statistical analysis. Statistical and the $\mathrm{IC}_{50}$ values (half maximal inhibitory concentration) calculations were carried out using GraphPad Prism software version 6. The flow cytometry analysis and gene expression data results were determined using multiple t-tests (Holm-Sidak method). All data were displayed as means $\pm \mathrm{SD}$ (standard deviation). * signifies the significant difference when $\mathrm{p}<0.05$.

\section{References}

1. Bray, F. et al. Global cancer statistics 2018: GLOBOCAN estimates of incidence and 
mortality worldwide for 36 cancers in 185 countries. CA. Cancer J. Clin. 68, 394-424 (2018).

2. Torre, L. A. et al. Global cancer statistics, 2012. CA Cancer J Clin 65, 87-108 (2015).

3. Thun, M. J., DeLancey, J. O., Center, M. M., Jemal, A. \& Ward, E. M. The global burden of cancer: priorities for prevention. Carcinogenesis 31, 100-110 (2010).

4. Sankaranarayanan, R., Ramadas, K. \& Qiao, Y. Managing the changing burden of cancer in Asia. BMC Med. 12, 3 (2014).

5. Azizah, A. M., Nor Saleha, I. T., Noor Hashimah, A., Asmah, Z. A. \& Mastulu, W. Malaysian National Cancer Registry Report 2007-2011: Malaysia Cancer Statistic, Data and Figure. Malaysia Natl. Cancer Inst. (2016).

6. Lukong, K. E. Understanding breast cancer - The long and winding road. BBA Clin. 7, 64-77 (2017).

7. Blumen, H., Fitch, K. \& Polkus, V. Comparison of treatment costs for breast cancer, by tumor stage and type of service. Am. Heal. drug benefits 9, 23-32 (2016).

8. Trogdon, J. G. et al. Medical costs of treating breast cancer among younger Medicaid beneficiaries by stage at diagnosis. Breast Cancer Res. Treat. 166, 207-215 (2017).

9. Rayan, A., Raiyn, J. \& Falah, M. Nature is the best source of anticancer drugs: Indexing natural products for their anticancer bioactivity. PLoS One 12, e0187925 (2017).

10. Newman, D. J. \& Cragg, G. M. Natural products as sources of new drugs from 1981 to 2014. J. Nat. Prod. 79, 629-661 (2016). 
11. Shah, U., Shah, R., Acharya, S. \& Acharya, N. Novel anticancer agents from plant sources. Chin. J. Nat. Med. 11, 16-23 (2013).

12. Dubey, A., Nayak, S. \& Goupale, D. C. A review on phytochemical, pharmacological and toxicological studies on Neolamarckia cadamba. Der. Pharm. Let 3, 45-54 (2011).

13. Pandey, A. \& Negi, P. S. Traditional uses, phytochemistry and pharmacological properties of Neolamarckia cadamba: A review. J. Ethnopharmacol. 181, 118-135 (2016).

14. Kaur, S. \& Kumar, S. Studies on the genoprotective/antioxidant potential of methanol extract of Anthocephalus cadamba (Roxb.) Miq. J. Med. Plants Res. 5, 4764-4770 (2011).

15. Chandel, M., Sharma, U., Kumar, N., Singh, B. \& Kaur, S. Antioxidant activity and identification of bioactive compounds from leaves of Anthocephalus cadamba by ultraperformance liquid chromatography/electrospray ionization quadrupole time of flight mass spectrometry. Asian Pac. J. Trop. Med. 5, 977-985 (2012).

16. Ahmed, F. et al. Evaluation of Neolamarckia cadamba (Roxb.) Bosser leaf extract on glucose tolerance in glucose-induced hyperglycemic mice. African J. Tradit. Complement. Altern. Med. 8, 79-81 (2011).

17. Dolai, N. et al. Evaluation of antitumor activity and in vivo antioxidant status of Anthocephalus cadamba on Ehrlich ascites carcinoma treated mice. J. Ethnopharmacol. 142, 865-870 (2012).

18. Mondal, S., Dash, G. K. \& Acharyya, S. Analgesic, anti-inflammatory and antipyretic studies of Neolamarckia cadamba barks. J. Pharm. Res. 2, 1133-1136 (2009). 
19. Rafshanjani, M., Shuaib, A., Parvin, S. \& Kader, M. Antimicrobial and Preliminary Cytotoxic effects of Ethanol extract and its fractions of Anthocephalus cadamba (Roxb.) Miqstem bark. Int. J. Pharm. Life Sci. 5, 4038-4044 (2014).

20. Singh, S., Ishar, M. P. S., Saxena, A. K. \& Kaur, A. Cytotoxic effect of Anthocephalus cadamba Miq. leaves on human cancer cell lines. Pharmacogn. J. 5, 127-129 (2013).

21. Lin, L. et al. Incidence and death in 29 cancer groups in 2017 and trend analysis from 1990 to 2017 from the global burden of disease study. J. Hematol. Oncol. 12, 96 (2019).

22. Harbeck, N. et al. Breast cancer (Primer). Nat. Rev. Dis. Prim. (2019).

23. Lin, T.-H. et al. D-pinitol inhibits prostate cancer metastasis through inhibition of $\alpha \mathrm{V} \beta 3$ integrin by modulating FAK, c-Src and NF-кB pathways. Int. J. Mol. Sci. 14, 9790-9802 (2013).

24. Rengarajan, T. et al. D-pinitol promotes apoptosis in MCF-7 cells via induction of p53 and Bax and inhibition of Bcl-2 and NF-אB. Asian Pac J Cancer Prev 15, 1757-1762 (2014).

25. Javadi, N. et al. Effect of storage time on metabolite profile and alpha-glucosidase inhibitory activity of Cosmos caudatus leaves - GCMS based metabolomics approach. J. Food Drug Anal. 23, 433-441 (2015).

26. Liu, M., Chen, Y.-L., Kuo, Y.-H., Lu, M.-K. \& Liao, C.-C. Aqueous extract of Sapindus mukorossi induced cell death of A549 cells and exhibited antitumor property in vivo. Sci. Rep. 8, 4831 (2018). 
27. Artini, P. G. et al. Endocrine and clinical effects of myo-inositol administration in polycystic ovary syndrome. A randomized study. Gynecol. Endocrinol. 29, 375-379 (2013).

28. Zayed, M. Z., Ahmad, F. B., Ho, W.-S. \& Pang, S.-L. GC-MS analysis of phytochemical constituents in leaf extracts of Neolamarckia cadamba (Rubiaceae) from Malaysia. Int J Pharm Pharm Sci 6, 123-127 (2014).

29. Ravi, L. \& Krishnan, K. Cytotoxic potential of N-hexadecanoic acid extracted from Kigelia pinnata leaves. Asian J. Cell Biol 12, 20-27 (2017).

30. Evans, L. M., Cowey, S. L., Siegal, G. P. \& Hardy, R. W. Stearate preferentially induces apoptosis in human breast cancer cells. Nutr. Cancer 61, 746-753 (2009).

31. Mericli, F. et al. Fatty acid composition and anticancer activity in colon carcinoma cell lines of Prunus dulcis seed oil. Pharm. Biol. 55, 1239-1248 (2017).

32. Xavier, A. P., Santharam, L., Panigrahi, S., Muthuraman, M. S. \& Pemiah, B. Antitumor potential of ethanolic extract of Solanum trilobatum against Ehrlich's Ascites Carcinoma. Int. J. Pharm Tech Res. 5, 1119-1125 (2013).

33. Sun, J. \& Hai Liu, R. Cranberry phytochemical extracts induce cell cycle arrest and apoptosis in human MCF-7 breast cancer cells. Cancer Lett. 241, 124-134 (2006).

34. Ouyang, L. et al. Programmed cell death pathways in cancer: a review of apoptosis, autophagy and programmed necrosis. Cell Prolif. 45, 487-498 (2012).

35. Khairi, M., Shamsuddin, S. \& Jaafar, H. Effects of rapamycin on cell apoptosis in MCF-7 
human breast cancer cells. Asian Pacific J. Cancer Prev. 15, 10659-10663 (2014).

36. Wen, Y. et al. Quantitative analysis and comparison of 3D morphology between viable and apoptotic MCF-7 breast cancer cells and characterization of nuclear fragmentation. PLoS One 12, e0184726 (2017).

37. Lowe, S. W. \& Lin, A. W. Apoptosis in cancer . Carcinogenesis 21, 485-495 (2000).

38. Martin, S. J. et al. Early redistribution of plasma membrane phosphatidylserine is a general feature of apoptosis regardless of the initiating stimulus: inhibition by overexpression of Bcl-2 and Abl. J. Exp. Med. 182, 1545-1556 (1995).

39. Riedl, S. et al. In search of a novel target - Phosphatidylserine exposed by non-apoptotic tumor cells and metastases of malignancies with poor treatment efficacy. Biochim. Biophys. Acta - Biomembr. 1808, 2638-2645 (2011).

40. Poon, I. K. H., Hulett, M. D. \& Parish, C. R. Molecular mechanisms of late apoptotic/necrotic cell clearance. Cell Death Differ. 17, 381-397 (2010).

41. Hanahan, D. \& Weinberg, R. A. The Hallmarks of Cancer. Cell 100, 57-70 (2000).

42. Choi, E. J. \& Kim, G.-H. Daidzein causes cell cycle arrest at the G1 and G2/M phases in human breast cancer MCF-7 and MDA-MB-453 cells. Phytomedicine 15, 683-690 (2008).

43. Fan, W. et al. Marsdenia tenacissima extract induces G0/G1 cell cycle arrest in human esophageal carcinoma cells by inhibiting mitogen-activated protein kinase (MAPK) signaling pathway. Chin. J. Nat. Med. 13, 428-437 (2015). 
44. Karade, P. G. \& Jadhav, N. R. In vitro studies of the anticancer action of Tectaria cicutaria in human cancer cell lines: G0/G1 p53-associated cell cycle arrest-Part I. $J$. Tradit. Complement. Med. 8, 459-464 (2018).

45. Xiong, J., Fan, F., Zhang, Y., Chen, W. \& Mao, W. Epirubicin inhibits proliferation of breast cancer cells through upregulating p21 (cip1) expression. Int. J. Clin. Exp. Med. 9, 22764-22772 (2016).

46. Vermeulen, K., Van Bockstaele, D. R. \& Berneman, Z. N. The cell cycle: a review of regulation, deregulation and therapeutic targets in cancer. Cell Prolif. 36, 131-149 (2003).

47. Kilbride, S. M. \& Prehn, J. H. M. Central roles of apoptotic proteins in mitochondrial function. Oncogene 32, 2703-2711 (2013).

48. Adams, J. M. \& Cory, S. Bcl-2-regulated apoptosis: mechanism and therapeutic potential. Curr. Opin. Immunol. 19, 488-496 (2007).

49. Gupta, S. Molecular steps of death receptor and mitochondrial pathways of apoptosis. Life Sci. 69, 2957-2964 (2001).

50. Westphal, D., Dewson, G., Czabotar, P. E. \& Kluck, R. M. Molecular biology of Bax and Bak activation and action. Biochim. Biophys. Acta - Mol. Cell Res. 1813, 521-531 (2011).

51. Duclos, C., Lavoie, C. \& Denault, J.-B. Caspases rule the intracellular trafficking cartel. FEBS J. 284, 1394-1420 (2017).

52. Hassan, M., Watari, H., AbuAlmaaty, A., Ohba, Y. \& Sakuragi, N. Apoptosis and Molecular Targeting Therapy in Cancer. Biomed Res. Int. 2014, 150845 (2014). 
53. Wakasugi, E. et al. $\mathrm{P} 21$ (Waf1/Cipl) and 553 protein expression in breast cancer. Am. J. Clin. Pathol. 107, 684-691 (1997).

54. Harper, J. W. et al. Inhibition of cyclin-dependent kinases by p21. Mol. Biol. Cell 6, 387400 (1995).

55. Xiong, Y. et al. p21 is a universal inhibitor of cyclin kinases. Nature 366, 701-704 (1993).

56. Gogada, R. et al. Curcumin induces Apaf-1-dependent, p21-mediated caspase activation and apoptosis. Cell Cycle 10, 4128-4137 (2011).

57. Zhou, M. et al. Atomic structure of the apoptosome: mechanism of cytochrome c-and dATP-mediated activation of Apaf-1. Genes Dev. 29, 2349-2361 (2015).

58. Khan, A.Y.F. et al. Anticancer activity of grassy Hystrix brachyura bezoar and its mechanisms of action: An in vitro and in vivo based study. Biomed Pharmacother. 114, 113 (2019).

59. Strober, W. Trypan blue exclusion test of cell viability. Curr Protoc Immunol., 21, A-3B (2015).

Acknowledgments: We acknowledge technical assistance and equipment by Molecular Laboratory staff of Kulliyyah of Medicine, Central Research and Animal Facility Cream (CREAM) and Department of Pharmaceutical Chemistry, Kulliyyah of Pharmacy in International Islamic University Malaysia (IIUM). Thanks to Airlangga University for the invitation in Adjunct Professorship Program 2019. H. R. El-Seedi are very grateful to the 
Swedish Research links grant VR 2016-05885 and the Department of Molecular Biosciences, Wenner-Grens Institute, Stockholm University, Sweden, for the financial support.

\section{Author Contributions}

Conceptualization, R.A.W. and A.K.; methodology, S.R. and T.K.J.; software, R.A.W.;

validation, R.A.W., A.K and Q.U.A.; formal analysis, S.R. and A.Y.F.K.; investigation, S.R. and A.Y.F.K.; resources, H.H.; data curation, T.K.J. and S.M.; writing—original draft preparation, S.R.; writing—review and editing, A.K., H.R.E.-S, M.M.A, Q.U.A.; H.H.; S.M.; M.I.; J.S.; S.A.M.K. and R.A.W.; visualization, S.R.; supervision, A.K; Q.U.A. and R.A.W.; project administration, A.K. and R.A.W.; funding acquisition, A.K.; M.I.; J.S.; H.R.E.-S. and R.A.W. Funding: This research was funded by Malaysian Ministry of Education, grant number FRGS 16-046-0545 (Granted to A.K), IIUM Publication Research Initiative Grant fund, grant number PRIGS18-027-0027 (Granted to A.K) and the Swedish Research Council Vetenskapsrådet, VR Grant 2016-05885 (Granted to H.R.E-S).

\section{Additional information}

Supplementary information accompanies this paper at

Competing interests: The author(s) declare no competing interests. 
A)

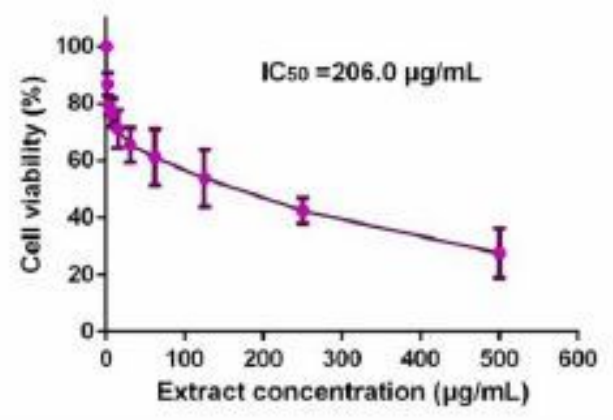

C)

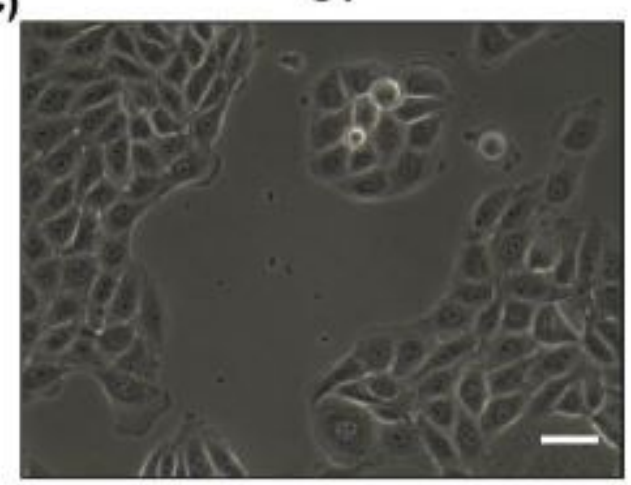

D)
B)

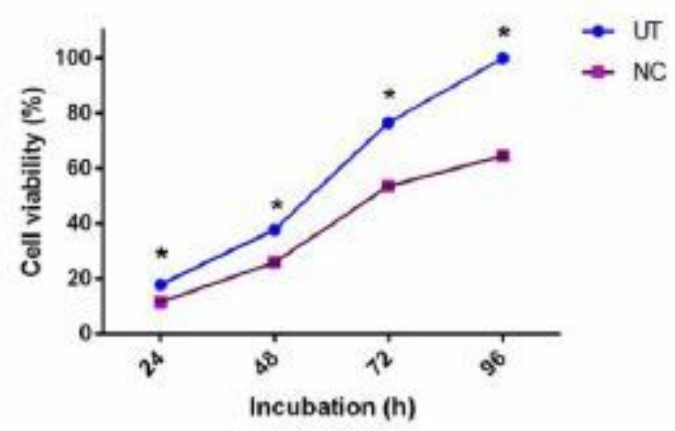

NC

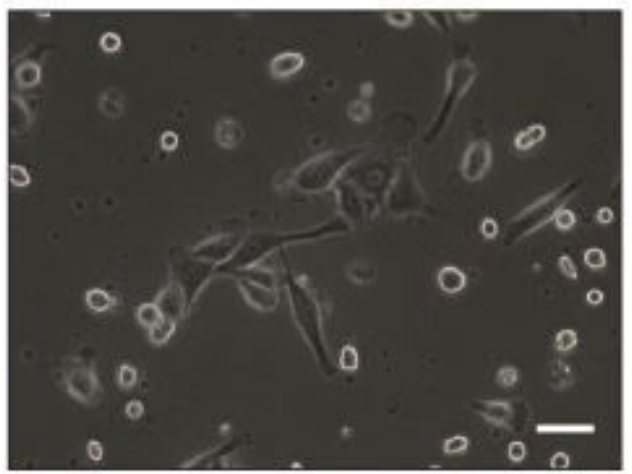

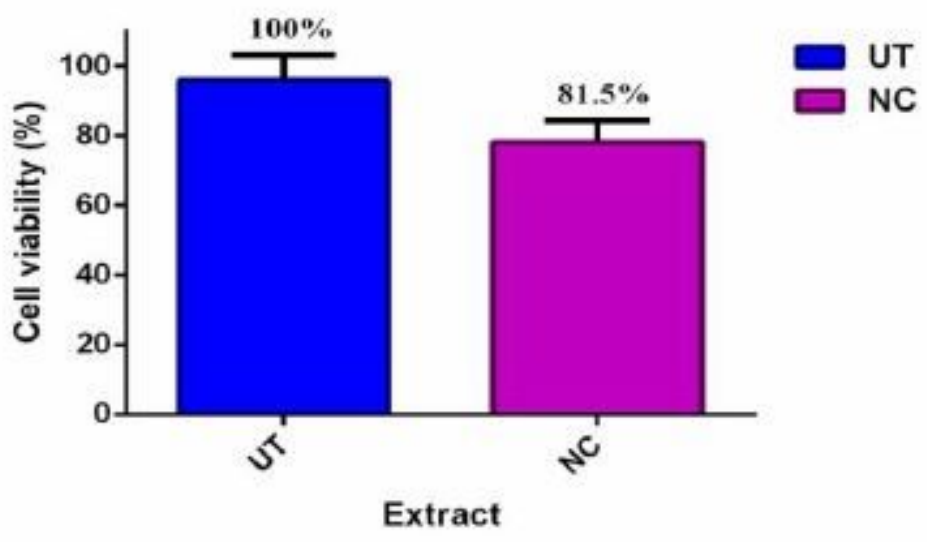

Figure 1

The effect of NC leaves $80 \%$ ethanol extract on MCF-7 cells viability. (A) The median concentration of MCF-7 treated with NC leaves $80 \%$ ethanol extract for 72 h. (B) Anti-proliferative effect of NC leaves $80 \%$ ethanol extract at 24, 28, 72, and $96 \mathrm{~h}$ with untreated cells (UT) as controls. (C) Image of MCF-7 cells NC leaves $80 \%$ ethanol extract treated and untreated at 72 h. (D) Cytotoxic effect of NC leaves $80 \%$ ethanol 
extract median concentration on normal human dermal fibroblast (HDF) cells at $72 \mathrm{~h}$ incubation. The results presented as mean $\pm S D(n=3)$. Bar graph $=25 \mu \mathrm{m}$. * indicates $p<0.05$.

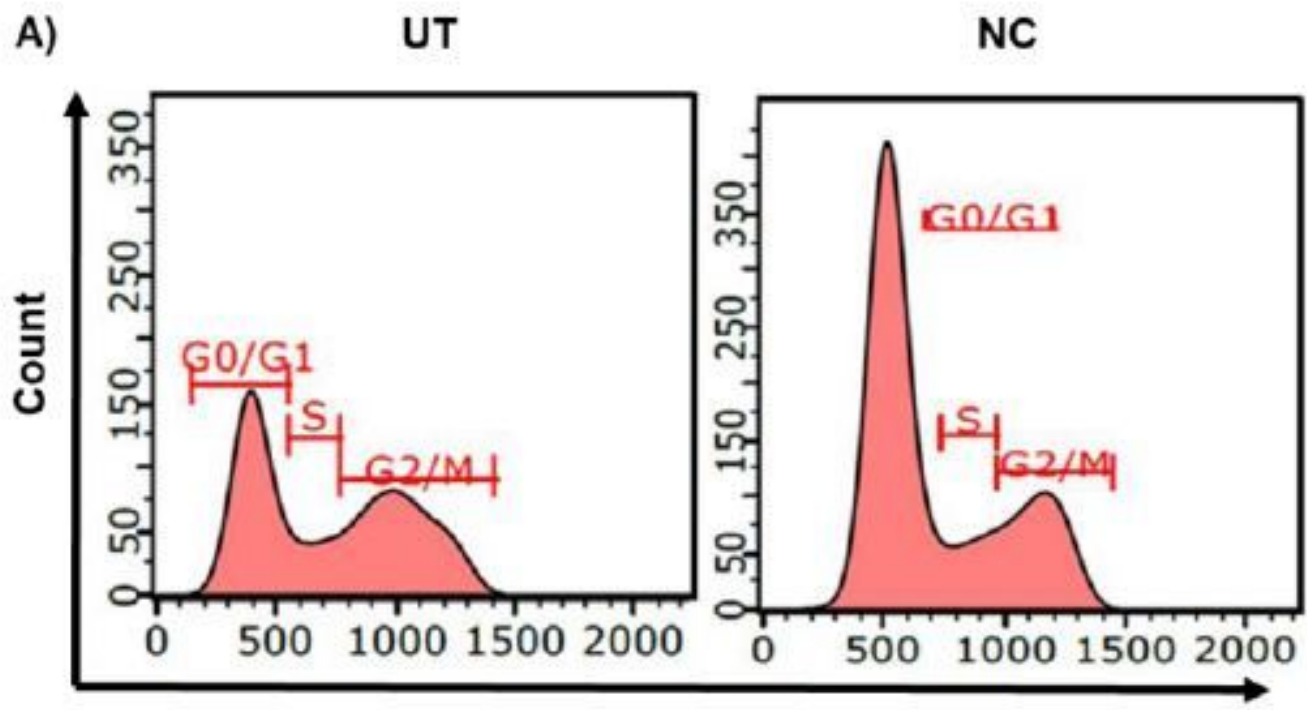

\section{Propidium lodide}

B)

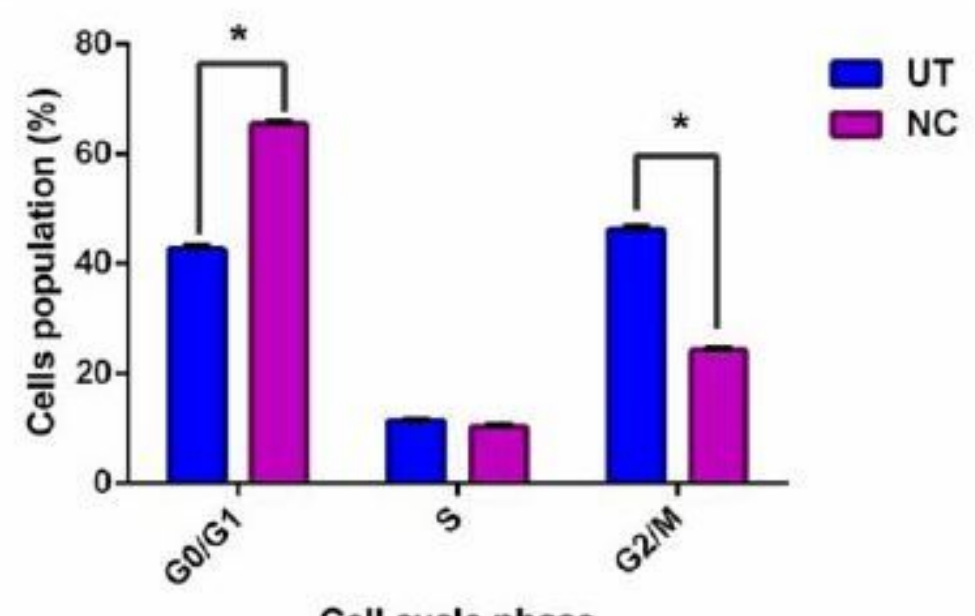

Cell cycle phase

Figure 2

The effect of NC leaves $80 \%$ ethanol extract on the MCF-7 cell cycle. (A) Representation of DNA histogram of NC leaves $80 \%$ ethanol extract-treated cells, with UT as control at $72 \mathrm{~h}$ of incubation. DNA histograms display cell cycle phases of treated cells, namely G1/G0, S, and G2/M ( $n=3)$. (B) The proportion of cells according to cell cycle phase are presented in percentage mean $\pm S D(n=3)$.* indicates $p<0.05$ concerning untreated. 


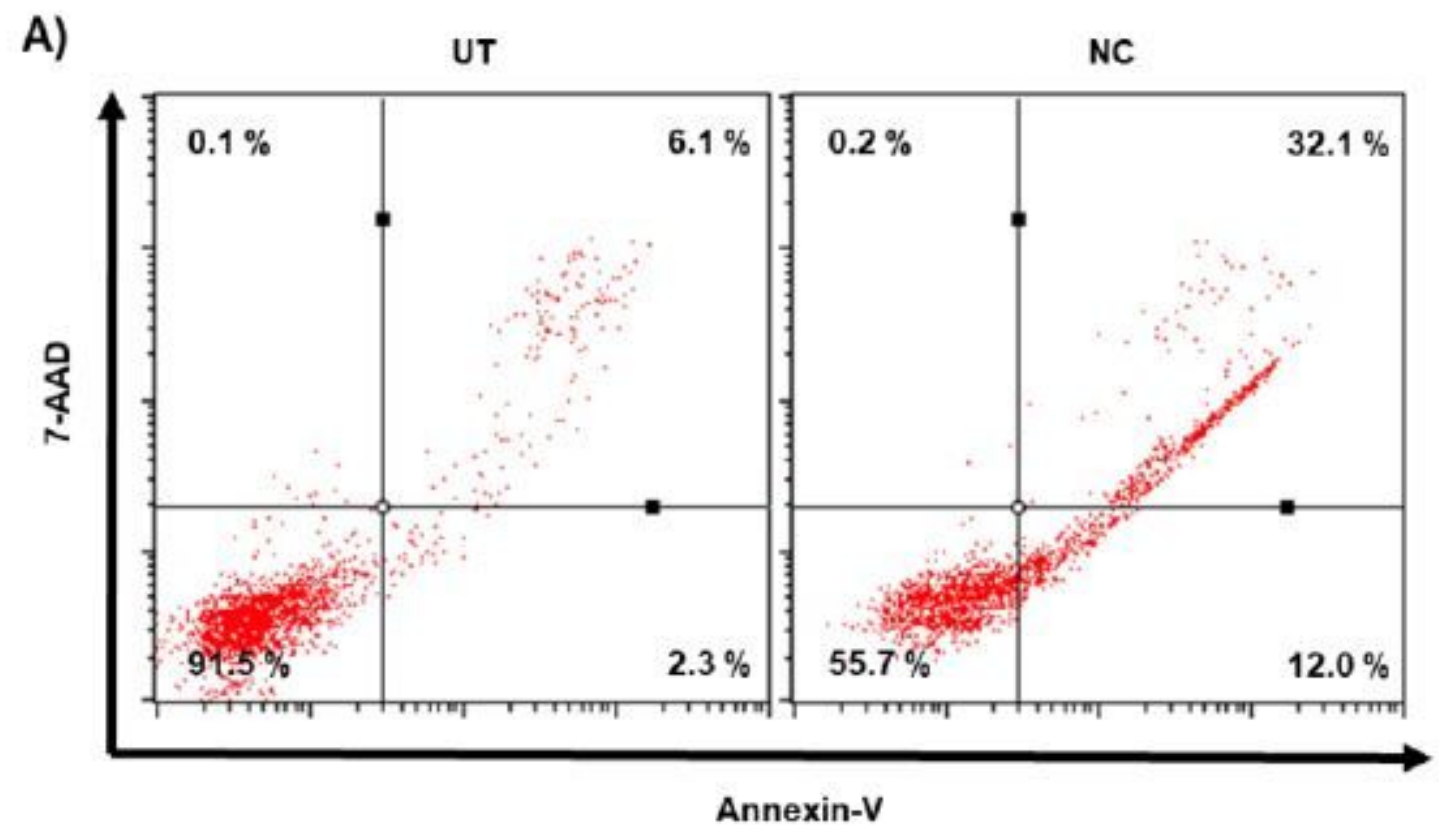

B)

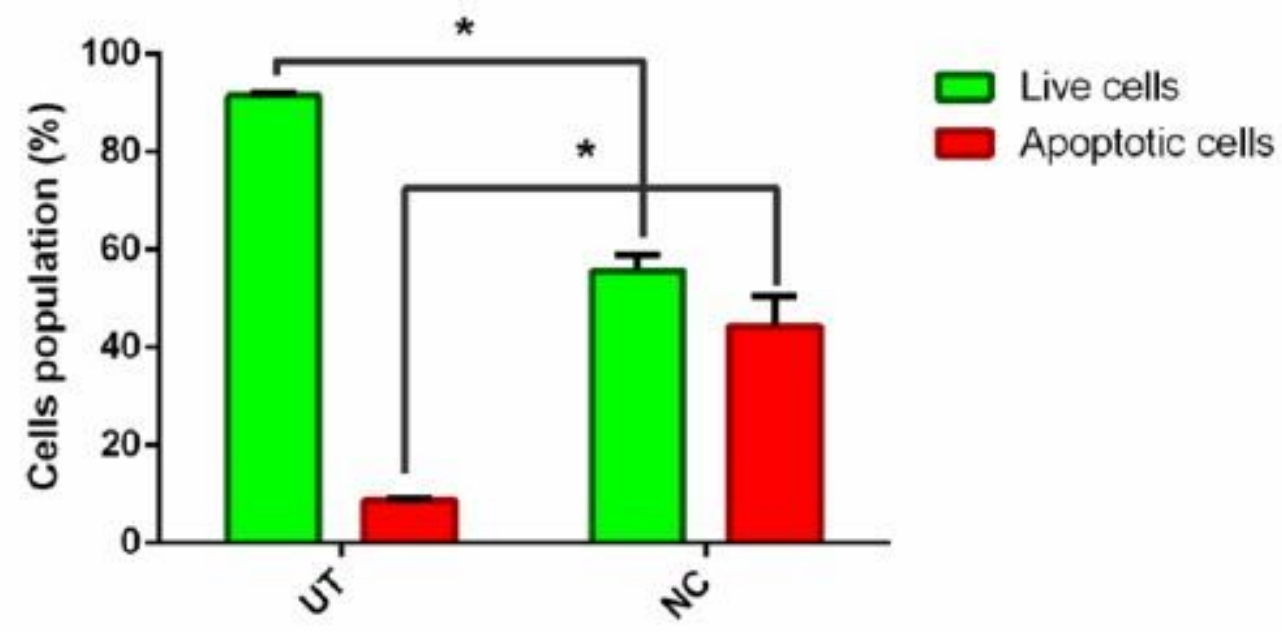

Type of extract

Figure 3

The effect of NC leaves $80 \%$ ethanol extract on MCF-7 cells. (A) Representation of dot plot distribution of cells in living, death, early and late apoptosis quadrants of MCF-7 cells treated with NC leaves $80 \%$ ethanol extract at $72 \mathrm{~h}$ with UT as control, $(n=3)$. (B) The proportion percentages of apoptotic (early and late apoptosis) and live cells are presented as percentage mean $\pm S D(n=3)$. * indicates $p<0.05$ concerning untreated. 


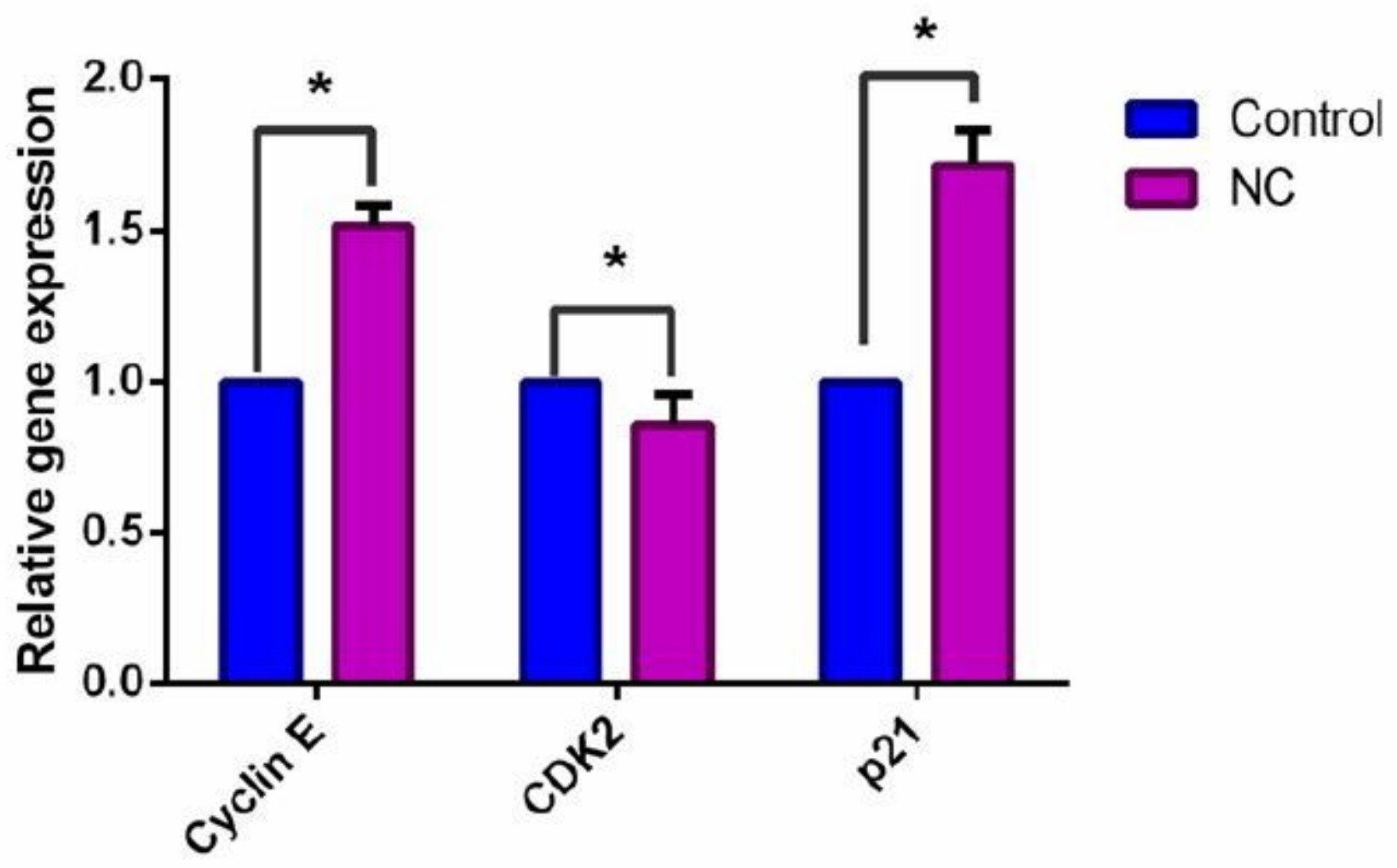

Genes

Figure 4

Effect of NC leaves $80 \%$ ethanol extract on cell cycle-related gene expression upon treatment with IC50 for $72 \mathrm{~h}$. Relative expression for cyclin E, CDK2, and p21 were calculated by measuring the fold change with GAPDH and $\beta$-actin as reference genes in untreated cells (the ratio was equal to 1 ). Data presented in mean \pm standard deviation of triplicates of the experiment. * indicates a significant difference when $p<$ 0.05 . 
A)

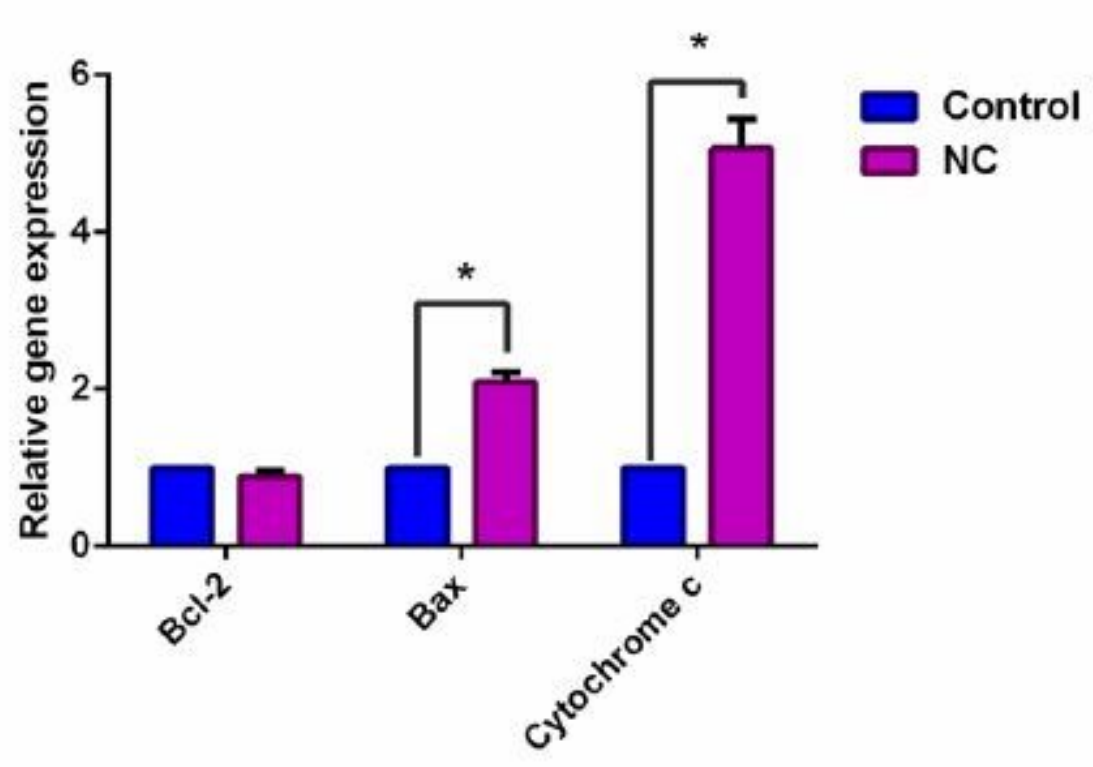

Genes

B)

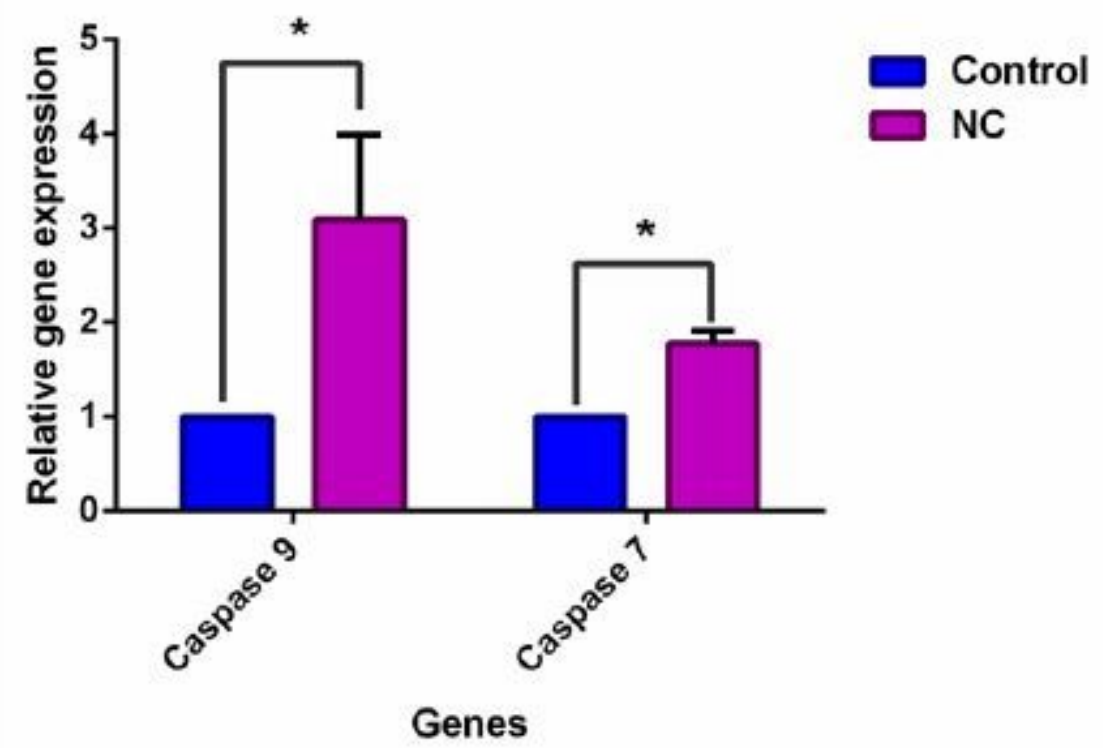

Figure 5

Effect of NC leaves $80 \%$ ethanol extract on apoptosis-related gene expression upon treatment with IC50 for $72 \mathrm{~h}$. Relative expression for (a) Bcl-2, Bax and cytochrome c, and (b) caspase-9 and caspase-7 were calculated by measuring the fold change with GAPDH and $\beta$-actin as a reference gene in untreated cells, whose ratio was equal to 1 . Data presented in mean \pm standard deviation of triplicates of the experiment. * indicates a significant difference when $p<0.05$.

\section{Supplementary Files}

This is a list of supplementary files associated with this preprint. Click to download. 
- Supplementaryinformation9jan.pdf 